\title{
PERSPECTIVE
}

\section{A clinical nutritionist's experience and expectations}

\author{
WPT James
}

European Journal of Clinical Nutrition (2017) 71, 915-918; doi:10.1038/ejcn.2017.95; published online 21 June 2017

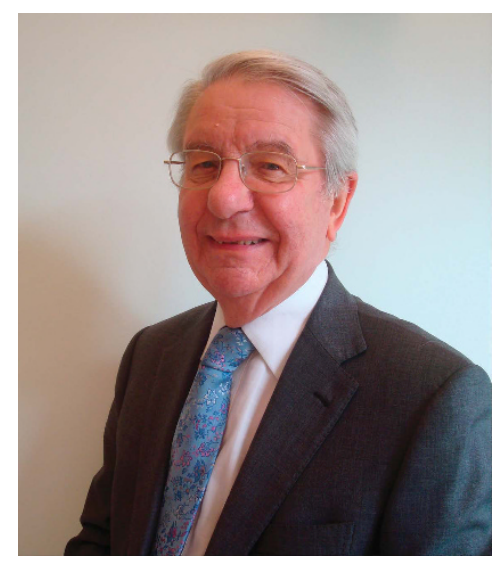

It is often said that those of us who end up in clinical nutrition get there by accident and I am no exception. I was brought up in Bala, North Wales and schooled in Yorkshire where I soon decided to do medicine and applied to University College Hospital and was asked to attend for interview. But on arrival I was told that the exam had been the previous week. Then discovering their mistake I was taken to see three old men who asked me how I had got there. I explained I was on my way to Saltsburg with a school group in a rebuilt old burned out Rolls Royce which I had rewired. We chatted for perhaps half an hour and then they concluded with a cheery 'See you next October!' Only later did I discover that the three Nobelists, Julian Huxley, AV Hill and Bernard Katz interviewing me must have been impressed by my primitive manual skills!

At medical school I was ill and admitted in the hospital early on, and was visited by a staff member who asked me to write an essay where I assumed I had suddenly lost 1.5-2 I of blood. I had to make it up but to my amazement the physiologist told me that he enjoyed my essay and offered me a scholarship to do a physiology degree once I had passed my 2nd MB exams in anatomy, physiology and so on, so this is what I did!

Medical school was fascinating but I soon found the clinicians boring and ignorant so I just read in the library; everybody assumed I was this quiet future general practitioner. However, to everybody's astonishment I got the highest set of honours marks in the finals so was given automatically the top house-job with Lord Max Rosenheim, the maestro of British medicine. That started with 6 months of intense work for up to $20 \mathrm{~h}$ a day. This taught me how to cope with intense pressure and led to 4 further jobs at University College Hospital and the Whittington hospitals. Then, after advanced medical qualifications (MRCP), I told Rosenheim I was leaving medieval British medicine and going abroad to do research. He asked me to wait and within days I was asked to go to the Medical Research Council (MRC) headquarters and was immediately offered a job in the Gambia for research on malaria. I politely refused as I was now married with a very young daughter. They panicked, asked me to wait and then produced an old guy, John Waterlow, who grilled me about kwashiorkor and potassium metabolism neither of which I knew anything. Nevertheless within minutes I was offered a job to undertake research in Jamaica on malnourished children.

This, in Jamaica, led to my new world of clinical nutrition. There I first studied albumin metabolism using the difficult ${ }^{131}$ isotope iodination technique. With a bright mathematical medical student, Andrew Hay, we showed the amazing adaptation in albumin metabolism to changes in protein intake in meticulously controlled studies. ${ }^{1}$ But I was interested in the gut so soon discovered how to facilitate gut biopsies in minute sick children, undertook the first mucosal disaccharidase assays in children, and invented a 5 lumen perfusion tube with dye dilution curves to assess motility and the recovery of mucosal function and absorption $^{2-4}$ (Figure 1a). However, with the new assays for insulin I also found pancreatic insulin secretory capacity did not recover $^{5}$ (Figure1b) which may perhaps explain Asian and Arab current sensitivities to diabetes. I then showed the need for both glucose and electrolytes to combat the jejunal secretory problem in infantile gastroenteritis. ${ }^{6}$ This, with the Dakka cholera group and Torres-Pinedo's research, led to the glucose-saline drink therapy for infantile diarrhoea and cholera that has already saved millions of lives.

I then returned to England and the London School of Hygiene to reorganise clinical and public health nutrition teaching for students. Research with Andrew Tomkins showed the detailed jejunal abnormalities and responsiveness to folic acid in tropical sprue, ${ }^{7}$ and we invented the $\mathrm{C}^{14}$-leucine turnover technique for Waterlow. ${ }^{8}$ On my first special diplomatically fraught trip for the UK Foreign Office to assess the need for school meals in the Montserrat I realised that childhood malnutrition was dominated by stunting so invented the wasting/stunting distinction that became the Waterlow classification of malnutrition! ${ }^{9}$ Later Anna Ferro-Luzzi and I generated the current UN criteria for adult malnutrition ${ }^{10}$ and changed the mathematical estimation of FAO's undernourished. Then after submitting a grant to the Health Ministry for research on the new problem of obesity I was asked, under Waterlow's chairmanship, to produce the first national report on obesity where I introduced the normal body mass index (BMI) range based on the lowest mortality figures from US insurance statistics. $^{11}$

This promptly led to my being recruited to run a clinical section of the Cambridge MRC Dunn Nutrition Unit. There we discovered that the BMR in obesity was increased not decreased, ${ }^{12}$ that familial obesity had dietary and other thermogenic abnormalities with hypothalamic abnormalities ${ }^{13}$ so brown fat became Mike Lean's focus. ${ }^{14}$ Murgatroyd built several whole-body calorimeters where we measured reproducible $24 \mathrm{~h}$ energy expenditures to

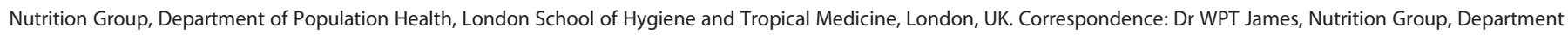
of Population Health, London School of Hygiene and Tropical Medicine, Keppel Street, Flat 1 Gatti's Wharf, 5, New Wharf Road, London N19RS, UK. 
a

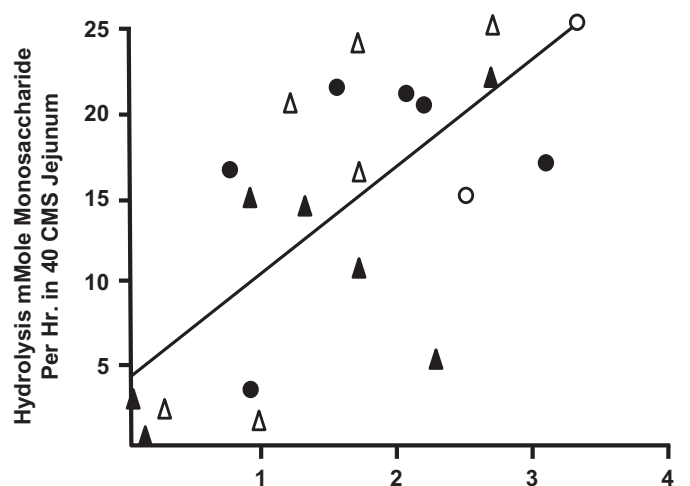

$\mu$ Mole Disaccharide Hydrolysed / Gram wet wt./min.

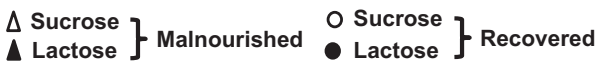

b

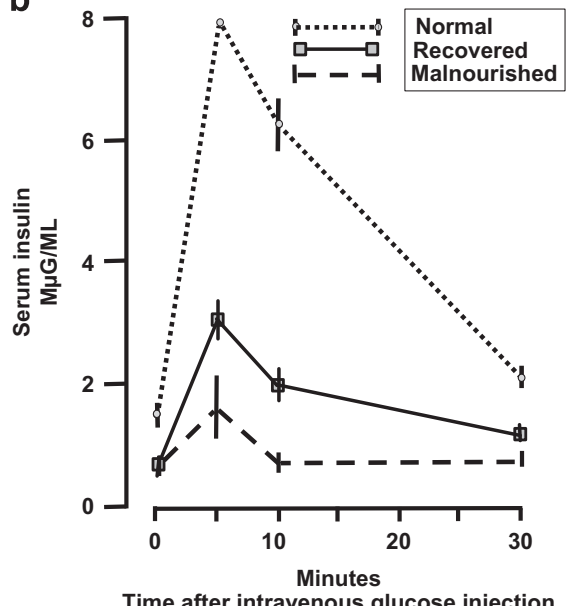

Figure 1. (a) The dependence of jejunal lactose and sucrose absorption on the level of disaccharidase activity in the jejunal mucosa of malnourished and recovered children with improvements, particularly in lactase activity with greater lactose hydrolysis and absorption of its constituent monosaccharides on recovery. Figure redrawn with permission from the New York Academy of Sciences. ${ }^{2}$ (b) The response in insulin secretion to a standard intravenous glucose challenge of $0.5 \mathrm{~g}$ glucose $/ \mathrm{kg}$ body weight showing that there is an exceptionally poor pancreatic response in malnourished children compared with normal children but many months later the recovered children still have a markedly subnormal response. Redrawn with permission from American Journal of Clinical Nutrition. ${ }^{5}$

$0.7 \%$ accuracy ${ }^{15}$ and validated the $\mathrm{D}_{2} \mathrm{O}^{18}$ technique in $\operatorname{man}^{16}$ within a full metabolic suite that sustained a large range of meticulous metabolic studies. We also proposed that total dietary fat was a prime inducer of obesity, thereby anticipating the marvellous studies of my future staff member James Stubbs. We developed laboratory, metabolic and epidemiological validations of a new lithium marker for assessing dietary sources of salt ${ }^{17}$ and worked with my colleague John Cummings on the effects of specially prepared food fibre in $\mathrm{kg}$ amounts ${ }^{18}$ and showed the colonic absorption of volatile fatty acids. ${ }^{19}$

This phenomenally high profile work led to me proposing a new Institute of Metabolic Medicine operating between the MRC Nobel Prize stacked Laboratory of Molecular Biology and the newly emerging Cambridge Medical School but this stimulated ruthless national political battles. Then by chance I heard that the Scottish Office and the scientific heads of the Ministry of Agriculture and Food and the Agriculture and Food Research Council wanted me to become Director of the Rowett Research Institute in Scotland with its 300 staff compared with my current 30 so that is where I finally ended up! To add to the controversy I was also battling the Ministry of Health to produce a new nutritional approach to public health set out in the NACNE report. ${ }^{20}$

At the Rowett I had to learn rapidly all about ruminant metabolism and agricultural policies but was also involved in major EU committees. I then proposed new agricultural approaches based on modern nutritional priorities rather than those of my Nobelist predecessor, Lord Boyd Orr with his emphasis on meat and fat for the protein and energy needs of the poor. For the next 17 years I directed a wide-ranging restructured institute in biological and nutritional research with a huge research output, but I also focused on new strategies for population's health including Scotland's (Figure 2 for multiple official reports). For WHO I chaired/wrote their first integrated new set of nutritional policies on nutritional deficiencies as well as noncommunicable diseases (WHO EURO 24 report) and, then in Geneva their global 979 Expert Technical report. I also chaired the Millennium report for the UN's Standing Committee for Nutrition emphasising the new concepts of maternal nutrition as crucial to infant and children's health and developed the life-course approach to nutritional public health (Figure 3).
My work then became ferociously political when Tony Blair suddenly asked me to develop an immediate strategy for coping with the endless UK crises on food safety, that is, the bovine spongiform encephalopathy and $E$. coli outbreaks and so on just 7 weeks before the election. This led to my proposing the Food Standards Agency which gained immediate secret acceptance by the Cabinet Secretary and then by Tony Blair himself on his first day in office. The restructuring of both the Ministries of Health and Agriculture was radical but I was immediately asked to see one of President Delors' senior assistants in Brussels. I advised that an EU Health Division was needed; DG SANCO was duly implemented. I then found myself as one of eight independent scientists on the EU's top Scientific Steering Committee and was immediately asked to personally devise within 6 weeks a completely new practical strategy to cope with the rapidly developing spread of bovine spongiform encephalopathy in Europe that threatened a European/USA trade war! Somehow I did this by assessing the probability of infectiveness of different organs from different ruminant species and developing principles for assessing the bovine spongiform encephalopathy risk profile of each trading country. This avoided trade disputes and is now current policy.

I also devised the first trials of orlistat and the STORM sibutramine trial with the new 500-600 kcal energy deficit diets. I still chair the Executive Steering Committee's of the 16-country sibutramine cardiovascular outcome SCOUT trial with further analysis and publications after 12 years study! ${ }^{21}$ My major drive, however, was establishing the International Obesity Task Force (IOTF) in 1996 which helped draft the WHO global 894 report on obesity. I then supported the IOTF criteria for childhood obesity before IOTF identified the whole basis of inter-sectoral factors generating obesity with numerous reports. I then established the International Association for the Study of Obesity as a legal charity with offices in London and then the European Association for the Study of Obesity. Then I amalgamated the IOTF with IASO, which became the World Obesity Federation.

Recently I challenged my wonderful colleague, Aubrey Sheiham (now deceased), on why he had proposed a $10 \%$ sugar limit to prevent dental decay in our contested 1990 WHO 797 report. This led to our proposal that sugar intake should be only $2-3 \%$ with a $5 \%$ maximum when optimum conditions of water fluoridation, and so on, apply. ${ }^{22}$ This helped WHO to generate its new 2016 5\% 


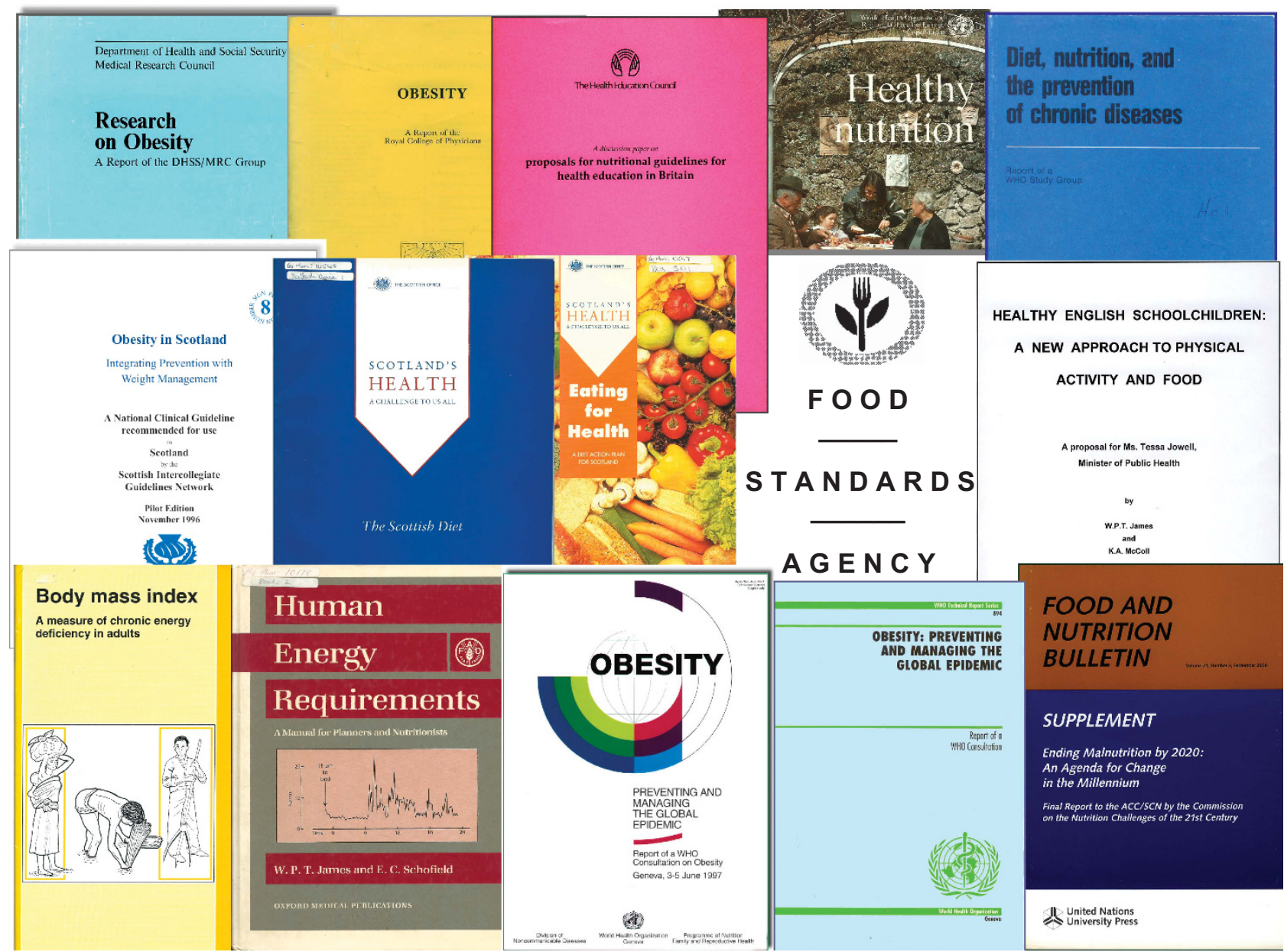

Figure 2. The Multiple reports produced for Ministers, Prime Ministers, WHO or the UN generally where I have chaired or launched the report having been a co-author or written the whole report. From left to right, top row: The First UK Dept. of Health/MRC report on obesity research 1976; The London Royal College report on obesity 1983; the UK NACNE report 1983; WHO EURO report Healthy Nutrition 1986; WHO Technical Expert series 797 Diet, nutrition and the prevention of chronic diseases1990. Second row: the first Scottish Intercollegiate Guidelines Network (SIGN) report on Obesity Management in Primary Care, 1996. No. 8; The Scottish Office's Scotland's Health: a challenge to us all: the Scottish Diet 1993. Then the Diet Action Plan for Scotland 1996; The UK Food Standards Agency Proposal for Tony Blair 1997; a new approach to physical activity and diet for English school children 1997. Third row: BMI, a measure of chronic energy deficiency for FAO by Prakash Shetty and James 1994; Human Energy Requirements; a manual for planners and nutritionists. For FAO with Clare Schofield 1990; the first WHO Obesity report distributed by IOTF1998; WHO formal Expert Technical Report Series 894 on Obesity, 2000; The UN SCN Millennium report on Ending Malnutrition by 2020. An agenda for change. Food and Nutrition Bulletin 2000; 21: No. 3S.

sugar proposal. Currently I am devising optimum practical policies with WHO Eastern Mediterranean colleagues for bread and other foods' salt reformulation, for banning trans fat production, limiting palm oil imports and use, and for fiscal and so on policies to tackle the high obesity rates in populations whom I have found are as supersensitive to diabetes as Asians and Mexicans (Figure 4).

So given this rather chaotic progression through life, essentially as an outsider rather than the usual establishment figure what might be the role for a clinical nutritionist in the future? Fortunately I am privileged to chair the Marabou Trust's scientific committee and the biennial think tanks in Stockholm on novel developments in nutrition. We almost always range from molecular biology to public health ,for example, when dealing with the nutritional significance of the gut microbiome ${ }^{25}$ or the nutritional role of microRNA, ${ }^{26}$ or in our current interest in epigenetics and the nutritional pressures on evolution and their dietary significance. This and the background in meticulous metabolic studies has taught me that the crude focus of a century ago on a limited set of essential nutritional factors was all very well but even our thinking on essential amino acids is now changing and the role of essential fatty acids needs new evaluation. There is also a host of other factors relating to genomic methylation, acetylation of the genome's supporting structures and the study of the control of stem cell programming that will lead to astonishing insights as will the seemingly blunderbuss instrumental scanning of the remarkable number of odd molecules pervading our tissues and now being related to the propensity to disease.

But the core to thinking straight is, I believe, an understanding that comes from the results of totally controlling the diet and other factors in metabolic studies and then measuring the body's physiological responses. When this is done properly it soon becomes apparent that the metabolic machinery relating to energy metabolism, nutrient processing or mineral balance is meticulously controlled in each individual who soon becomes a vivid responder with then a personally predictable and often proportionate response depending on their organ size or 


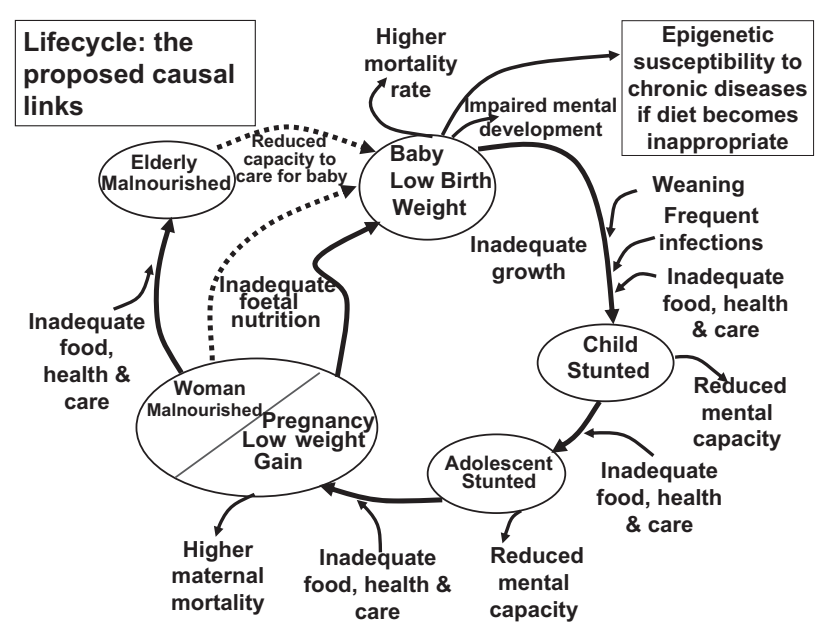

Figure 3. A life-course approach to nutritional problems. Adapted from James et al. The SCM Millennium Report. Food and Nutrition Bulletin 2000, 21:3S.

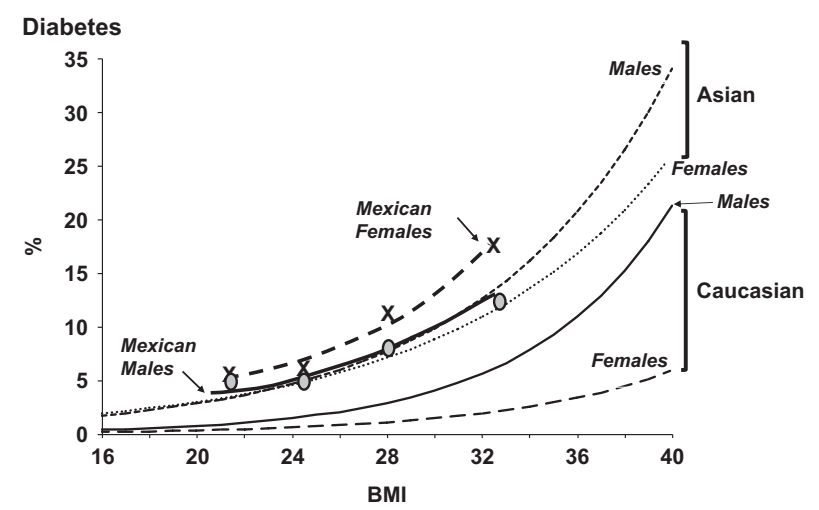

Figure 4. The propensity to selectively higher rates of diabetes than those expected in Australasians and non- Hispanic US whites (Caucasians) for their current BMI in Asians and Mexican men and women (a feature now also becoming evident in populations from the Eastern Mediterranean and North African countries). Data adapted from Huxley et al. ${ }^{23}$ and Sanchez-Castillo et al. ${ }^{24}$

enzymatic capacity. Investigators who think that everything is very variable clearly are not controlling their experiments with ruthless accuracy. From this understanding comes recognition of the individual variability in response within a society and therefore how flawed the current interpretation of cohort studies for policy making is when the conclusions rely on the supposition that we all have roughly the same response to a standard dietary intake (almost always measured by hopeless food frequency or worse techniques). The current mantra of policy making that relies on these types of cohort study were shown statistically to be flawed decades ago so we do need intervention studies in policy making but we should also include biomarkers and other validators of the variability in response in our cohort studies and recognise the validity and policy making insights that come from clinical nutrition. This is how we changed policy making when dealing with energy needs and the world's food supplies, the sources of salt in the diet, the impact of dietary fibre and its role and the importance of different macronutrients. So there is a rosy future for clinical nutrition but only if we project its importance as the real base for critical thinking when we come to considering the appropriate feeding of the population.

\section{CONFLICT OF INTEREST}

The author declare no conflict of interest.

\section{REFERENCES}

1 James WPT, Hay AM. Albumin metabolism: effect of the nutritional state and the dietary protein intake. J Clin Invest 1968; 47: 1958-1972.

2 James WPT. Sugar absorption and intestinal motility in children when malnourished and after treatment. Clin Sci 1970; 39: 305-318.

3 James WPT. Jejunal disaccharidase activities in children with marasmus and with kwashiorkor: the response to treatment. Arch Dis Chld 1971; 46: 218-220.

4 James WPT. Effects of protein-calorie malnutrition on intestinal absorption. Ann N Y Acad Sci 1971; 176: 244-261.

5 James WPT, Coore HG. Persistent impairment of insulin secretion and glucose tolerance after malnutrition. Am J Clin Nutr 1970); 23: 386-389.

6 James WPT, Drasar BS, Miller C. Physiological mechanism and pathogenesis of weanling diarrhoea. Am J Clin Nutr 1972); 25: 564-571.

7 Tomkins AM, James WPT, Walters JH, Cole ACE. Malabsorption in overland travellers to India. Br Med J 1974; 3: 380-384.

8 O'Keefe SJD, Sender PM, James WPT. 'Catabolic' loss of body nitrogen in response to surgery. Lancet 1974; 2: 1035-1038.

9 James WPT, Aksu B, Ferro-Luzzi A. Assessing the nutritional status of children and adults. In: Shetty Prakash (Editor). Nutrient Metabolism And Malnutrition: A festschrift for John Conrad Waterlow. Smith-Gordon: London: 2000; Chapter 14, 117-128.

10 James WPT, Ferro-Luzzi A, Waterlow JC. Definition of chronic energy deficiency in adults. Report of a Working Party of the International Dietary Energy Consultative Group. Eur J Clin Nutr 1988; 42: 969-981. See subsequent simplification: EJCN 1992; 46: 173-186.

11 James WPT (Compiler). Research on obesity. A report of the DHSS/MRC group. HMSO 1976.

12 James WPT, Davies HL, Bailes J, Dauncey MJ. Elevated metabolic rates in obesity. Lancet 1978; 1: 1122-1125.

13 Jung RT, Shetty PS, James WPT, Barrand MA, Callingham BA. Reduced thermogenesis in obesity. Nature 1979; 279: 322-323. see also Clinical Science 1981; 60: 519-525 and Lancet 1982, 1: 1043-1046.

14 Lean MEJ, James WPT, Jennings G, Trayhurn P. Brown adipose tissue uncoupling protein content in human infants, children and adults. Clin Sci 1986; 71: 291-297.

15 Dallosso HM, James WPT. Whole body calorimetry studies in adult men. 1 . The effect of fat over-feeding on 24 h energy expenditure. Br J Nutr 1984; 52: 49-64.

16 Klein PD, James WPT, Wong WW, Irving CS, Murgatroyd PR, Cabrera M et al. Calorimetric validation of the double-labelled water method for determination of energy expenditure in man. Hum Nutr Clin Nutr 1984; 38C: 95-106.

17 James WPT, Ralph A, Sanchez- Castillo CP. The dominance of salt in manufactured food in the sodium intake of affluent societies. Lancet 1987; 1: 426-429.

18 Cummings JH, Southgate DAT, Branch W, Houston H, James WPT. Colonic response to dietary fibre from carrot, cabbage, apple, bran and guar gum. Lancet 1978; 1: 5-9.

19 McNeil NI, Cummings JH, James WPT. Short chain fatty acid absorption by the human large intestine. Gut 1978; 19: 819-822.

20 Nutrition: the changing scene. Sequential extracts from the NACNE report. Lancet 1983: II: 719-721, 782-784, 835-838, 902-905. This reflected the editor's insistence that our report was published despite UK government opposition so he did it in 4 parts.

21 James WP, Caterson ID, Coutinho W, Finer N, Van Gaal LF, Maggioni AP et al. SCOUT Investigators. Effect of sibutramine on cardiovascular outcomes in overweight and obese subjects. N Engl J Med 2010; 363: 905-917.

22 Sheiham A, James WPT. Diet and dental caries - the pivotal role of free sugars reemphasized. J Dent Res 2015; 94: 1341-1347.

23 Huxley R, James WP, Barzi F, Patel JV, Lear SA, Suriyawongpaisal P et al. Ethnic comparisons of the cross-sectional relationships between measures of body size with diabetes and hypertension. Obes Rev 2008; 9: 51-63.

24 Sánchez-Castillo C, Velásquez-Monroy O, Lara-Esqueda A, Berber A, Sepulveda J, Tapia-Conyer $\mathrm{R}$ et al. Diabetes and hypertension increases in a society with abdominal obesity: results of the Mexican National Health Survey 2000. Public Health Nutr 2005; 8: 53-60.

25 James WPT, Gaza C. The human microbiome: an expanding digestive, physiological and metabolic role. Extended discussion and summary. Nutr Rev 2012; 2012: 57-86 and S87-94.

26 Nolte-'t Hoen EN, Van Rooij E, Bushell M, Zhang CY, Dashwood R, James WP et al. The role of microRNA in nutritional control. J Intern Med 2015; 278: 99-109. 